Article

\title{
One-Step Removal of Calcium, Magnesium, and Nickel in Desalination by Alcaligenes aquatilis via Biomineralization
}

\author{
Yaohua Dong ${ }^{1,2}$, Zhangwei Guo ${ }^{1, * \mathbb{D}}, \mathrm{Na} \mathrm{Guo}^{1}$ and Tao Liu ${ }^{1}$ \\ 1 College of Ocean Science and Engineering, Institute of Marine Materials Science and Engineering, \\ Shanghai Maritime University, Shanghai 201306, China; yhdong@shmtu.edu.cn (Y.D.); \\ naguo@shmtu.edu.cn (N.G.); liutao@shmtu.edu.cn (T.L.) \\ 2 School of Mechanical Engineering, Shanghai Jiaotong University, Shanghai 200240, China \\ * Correspondence: zwguo@shmtu.edu.cn
}

Received: 12 October 2019; Accepted: 26 November 2019; Published: 28 November 2019

\begin{abstract}
In desalination, a high level of calcium (Ca) and magnesium $(\mathrm{Mg})$ ions in seawater can cause scale deposition on the reverse osmosis membranes and water treatment systems. This process can significantly affect the efficiency of desalination. In addition, heavy metals in seawater affect human health. Therefore, Alcaligenes aquatilis from seawater was used to remove $\mathrm{Ca}, \mathrm{Mg}$, and nickel (Ni) by microbial-induced carbonate precipitation (MICP). The purification system was then analyzed by ionic analysis and surface characterization. This study shows that the bacteria can utilize amino acids to produce carbonate and form precipitates with a high removal rate. MICP via A. aquatilis removed $91.8 \%, 68.5 \%$, and $92.2 \%$ of the initial soluble $\mathrm{Ca}, \mathrm{Mg}$, and $\mathrm{Ni}$, respectively. Furthermore, A. aquatilis can remove ammonium after the MICP process under oxygen-rich conditions. Therefore, we provide interesting insight into the use of Alcaligenes (in the absence of urea) to improve the seawater quality in the process of desalination.
\end{abstract}

Keywords: Alcaligenes aquatilis; MICP; desalination; calcium; magnesium; nickel

\section{Introduction}

With the scarcity of freshwater resources, desalination has captured more attention due to the virtually inexhaustible supply of seawater [1,2]. Desalination can help guarantee a stable supply of freshwater for industrial and agricultural consumption [3]. However, a high level of calcium (Ca) and magnesium $(\mathrm{Mg})$ ions in seawater can cause scale deposition on the reverse osmosis membranes and water treatment systems, thus significantly affecting the efficiency of desalination [4]. Therefore, removal of secondary ions, such as calcium and magnesium, from seawater is a fundamental pretreatment for desalination. However, traditional disincrustant (e.g., sulfuric acid) often results in environmental pollution, cost increases, and corrosion of pipeline materials $[3,5]$.

Recently, microbial-induced carbonate precipitation (MICP) was reported to improve the quality of seawater and freshwater [6-8]. The formation of minerals is attributed to the cellular activity of living organisms, providing a suitable physicochemical condition for biomineralization. Furthermore, this strategy can simultaneously remove the $\mathrm{Ca}^{2+}, \mathrm{Mg}^{2+}$, and heavy metal ions, as the extracellular polymeric substance (EPS) on the bacteria surface can complex various cations. This complex generation is followed by the formation of insoluble and stable carbonate precipitation in the environment [9-11]. In MICP, urease-producing microorganisms are widely used due to the generation of carbonate ions through the hydrolysis of urea. This promotes the formation of carbonate via the enhancement of $\mathrm{pH}$ in the growth environment. Urease-producing microorganisms have recently been studied for removal of $\mathrm{Ca}, \mathrm{Mg}$, strontium ( $\mathrm{Sr}$ ), cadmium (Cd), copper 
$(\mathrm{Cu})$, and lead $(\mathrm{Pb})$ from water $[4,7,8,12,13]$. However, byproducts of ammonium from urease-producing microorganisms are toxic and harmful to organisms [14,15]. In addition, methods that use urease-producing microorganisms in desalination or wastewater treatment require extra urea inputs.

Alcaligenes is a type of nonpathogenic bacterium that is widespread in the ocean [16,17]. Most Alcaligenes can decompose amino acids and organic acids into ammonia and carbonate via an amination reaction in the absence of urea, and they exhibit the ability to remove $\mathrm{Ca}, \mathrm{Mg}$, and heavy metal ions from seawater [17-19]. This genus can convert ammonia into $\mathrm{N}_{2}$ in wastewater under an oxygen-rich environment, which could eliminate the toxicity of ammonia byproducts [20]. In this study, Alcaligenes aquatilis was used to investigate the MICP, and MICP was then subjected to ionic analysis and surface characterization. The experiment showed that the bacteria can utilize amino acids to produce carbonate and form precipitates with a high removal rate. Furthermore, A. aquatilis could remove ammonia after the MICP process under oxygen-rich conditions. Therefore, this study provides interesting insight into the use of Alcaligenes (in the absence of urea) to improve seawater quality in the process of desalination.

\section{Materials and Methods}

\subsection{Microorganisms}

A. aquatilis (Gram-negative, purchased form Marine Culture Collection of China) has been shown to decompose amino acids and organic acids to produce ammonia and carbonate via an amination reaction, without additional inputs of urea. This strain presented a high capability to form carbonate at temperatures ranging from 10 to $37^{\circ} \mathrm{C}$. Therefore, the A. aquatilis strain was selected to explore the removal of $\mathrm{Ca}, \mathrm{Mg}$, and heavy metal ions in seawater.

\subsection{Removal of $\mathrm{Ca}, \mathrm{Mg}$, Nickel (Ni), and Ammonia from Ni-Containing Seawater}

$\mathrm{Ni}$-containing seawater was obtained from a sea area beside a Ni-electroplating plant, and this seawater was analyzed to determine the levels of $\mathrm{Ca}, \mathrm{Mg}$, and $\mathrm{Ni}$ via inductively coupled plasma mass spectrometry (ICP-MS) (PerkinElmer NexION 2000, Waltham, Massachusetts, MA, United States) (Figure 1). For the removal of $\mathrm{Ca}, \mathrm{Mg}$, and $\mathrm{Ni}$ from this seawater, $10 \mathrm{~g} / \mathrm{L}$ of tryptone (Sinopharm Chemical ReagentCo., Ltd, Shanghai, China) and $5 \mathrm{~g} / \mathrm{L}$ of yeast extract (Sinopharm Chemical ReagentCo., Ltd., Shanghai, China) were added. Then, $100 \mu \mathrm{L}$ of bacteria cultured overnight were inoculated in this water after sterilization. After 5 days of cultivation at $37^{\circ} \mathrm{C}$ and $120 \mathrm{r} / \mathrm{min}$, the precipitate was filtered out and washed three times by ultrapure water. The obtained precipitate was used for further identification.

The $\mathrm{Ca}, \mathrm{Mg}$, and $\mathrm{Ni}$ concentrations in the seawater were investigated by ICP-MS in the first 5 days. Three replicates were measured in all cases, and the background correction was obtained using blank samples.

Removal of ammonium experiments were analyzed after the MICP process. In Figure 8, the efficacy of $A$. aquatilis was determined under oxygen-rich conditions in a $1 \mathrm{~L}$ reactor. After the MICP process, $500 \mathrm{~mL}$ of seawater was added to this reactor. Air was pumped into this reactor with a flow rate of $0.5 \mathrm{~L} / \mathrm{min}$. The liquid in this reactor was agitated at $120 \mathrm{r} / \mathrm{min}$ with a magnetic stirrer. The ammonia in the liquid was determined after 3 days. The gas in the top space of this reactor was delivered to the acid trap with $150 \mathrm{~mL}$ of $0.2 \mathrm{~mol} / \mathrm{L} \mathrm{H}_{2} \mathrm{SO}_{4}$ solution to capture escaped $\mathrm{NH}_{3}$ from the liquid. Then, the removal rate of ammonia was calculated (Table 1).

\subsection{Scanning Electron Microscope-Energy Dispersive Spectroscopy (SEM-EDS)}

The obtained precipitate was collected and dried at 160 centigrade for $24 \mathrm{~h}$. The precipitation samples were installed on a copper mount with a carbon conductive tape. The samples were then covered by a gold coating with a thickness of approximately $200 \mathrm{~A}$. The gold sputter coating was put on the carbon to increase the conductivity and reduce the charge of the specimen. Then, the samples were examined at $20 \mathrm{kV}$ using a JSM-7500F (JEOL, Tokyo, Japan) scanning electron microscope and an energy dispersive spectroscopy (EDS) system for elemental analysis. 


\subsection{Fourier-Transform Infrared (FTIR) Spectroscopy}

To investigate the involvement of the precipitation components after treatment, FTIR spectrum scanning was performed at a range of $4000-400 \mathrm{~cm}^{-1}$ with an interval of $0.96 \mathrm{~cm}^{-1}$. Thirty-two scans were obtained for each spectrum. Before analysis, the precipitation samples were ground evenly with $0.1 \mathrm{~g}$ of $\mathrm{KBr}$ in an agate mortar.

\subsection{X-Ray Diffraction (XRD)}

Phase identification of precipitation samples was carried out via X-ray diffraction (PANalytical, Almelo, Netherlands). This was done using a PANalytical X' Pert PRO XRD at $40 \mathrm{kV}$ and $10 \mathrm{~mA}$, with a $\mathrm{Cu} \mathrm{K} \alpha$ radiation source. Scanning was done within $2 \theta=20-90^{\circ}$ in steps of $0.06^{\circ}$ after immersion tests.

\subsection{Transmission Electron Microscope (TEM)}

The precipitation samples were investigated by TEM analysis (JEOL, Tokyo, Japan); polycrystalline and amorphous structures were obtained by selected area electron diffraction (SAED) pattern.

\subsection{X-Ray Photoelectron Spectroscopy (XPS)}

The precipitation samples were investigated via XPS analysis (AXIS UltraDLD, KRATOS, Shimadzu, Kyoto, Japan). XPS binding energy spectra of wide ranges were used $(0-1200 \mathrm{eV}$ at an emission angle of $\left.45^{\circ}\right) . \mathrm{C} 1 \mathrm{~s}, \mathrm{O} 1 \mathrm{~s}, \mathrm{Ca} 2 \mathrm{p}, \mathrm{Ni} 2 \mathrm{p} 3$, and $\mathrm{Cl} 2 \mathrm{p}$ were obtained to study the composition differences of precipitation. All high-resolution spectra were corrected using the $\mathrm{C} 1 \mathrm{~s}$ line at $284.6 \mathrm{eV}$.

\section{Results}

It was well known that the bacteria served as nuclei of carbonate precipitation via the biomineralization process, in which the $\mathrm{Ca}^{2+}$ and $\mathrm{Mg}^{2+}$ were adsorbed onto the EPS due to their negative surface charge. Therefore, biomineralization or MICP were proposed as a new strategy for pretreatment of seawater. Figure 1 shows that the A. aquatilis strain removed $41.4 \%$ and $56.2 \%$ of the initial soluble $\mathrm{Ca}^{2+}$ and $\mathrm{Mg}^{2+}$, respectively, after 1 day. After 5 days, $93.6 \%$ and $72.4 \%$ of the initial soluble $\mathrm{Ca}^{2+}$ and $\mathrm{Mg}^{2+}$ ions were removed, respectively. Meanwhile, the concentrations of $\mathrm{NH}_{4}{ }^{+}$increased from 0.12 to $47.8 \mathrm{mmol} / \mathrm{L}$. These results indicate that the soluble $\mathrm{Ca}^{2+}$ and $\mathrm{Mg}^{2+}$ concentrations decreased with the consumption of amino acids and organic acids, producing $\mathrm{CO}_{3}{ }^{2-}$, $\mathrm{HCO}_{3}{ }^{-}$, and $\mathrm{NH}_{4}{ }^{+}$. Additionally, seawater often contains heavy metal ions from industrial pollution, which is hazardous to marine organisms. Seawater medium containing approximately $4.23 \mathrm{mmol} / \mathrm{L}$ soluble-exchangeable $\mathrm{Ni}$, was also reduced to $0.29 \mathrm{mmol} / \mathrm{L}$ via bioprecipitation (Figure 1 ). In this process, $\mathrm{Ni}^{2+}$ was fixed into carbonate during cultivation of A. aquatilis. This indicates that the MICP process could deposit nickel via carbonate precipitation by A. aquatilis.
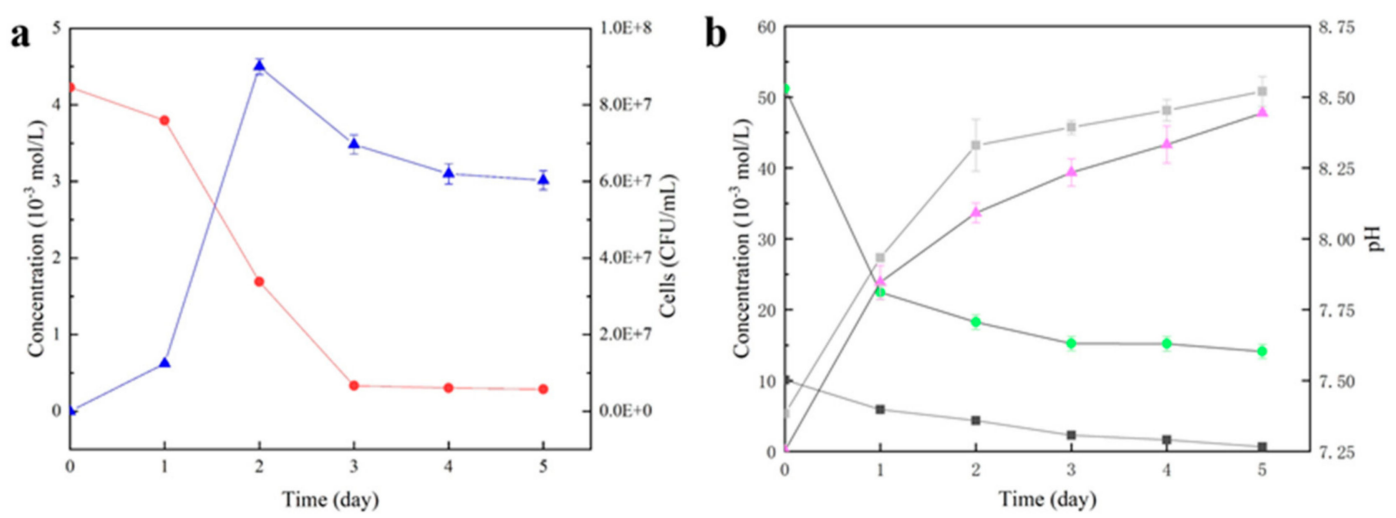

Figure 1. (a) Time curves of soluble $\mathrm{Ni}^{2+}$ (red circle) and cell number (blue triangle). (b) Time courses of $\mathrm{pH}$ (grey square), soluble $\mathrm{Mg}^{2+}$ (green circle), soluble $\mathrm{Ca}^{2+}$ (black square), and $\mathrm{NH}_{4}^{+}$(light magenta). 
For further investigation of the MICP in the remediation process, the samples from the natural seawater and Ni-containing seawater groups were analyzed by SEM-EDS. The SEM images show evident agglomeration of crystalline deposits on the samples (Figure 2a,b). The EDS spectra indicated that the main components of precipitate from normal seawater were Ca and $\mathrm{Mg}$ (Figure 2c). As shown in Figure 2b, a large portion of $\mathrm{Ni}$ appeared on the bioprecipitate of the Ni-containing seawater (Figure 2b).

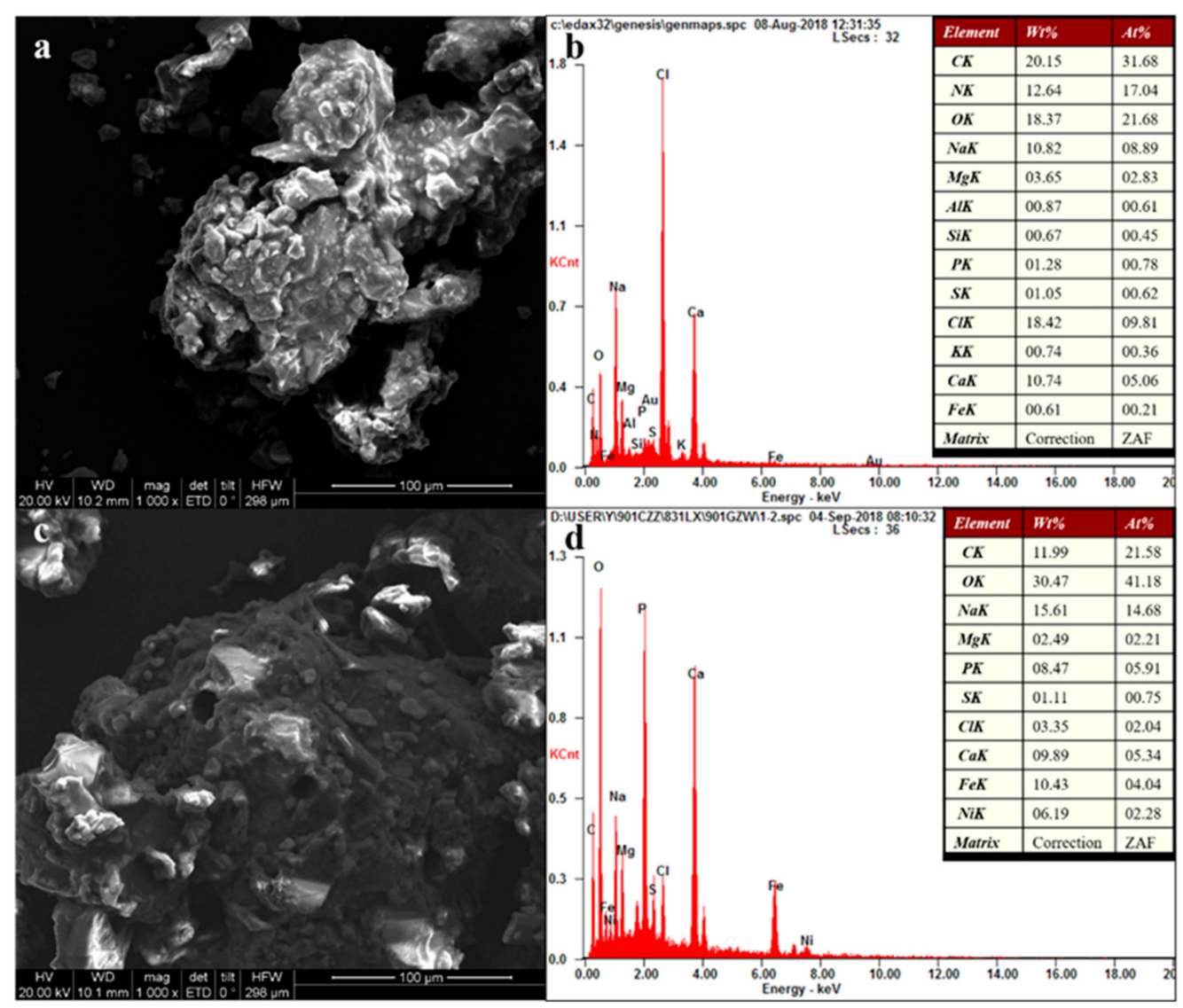

Figure 2. Scanning electron microscopy results of (a) normal seawater (SW) and (c) Ni-containing precipitate produced by A. aquatilis. A typical image is shown from many similar examples. EDS results for (b) normal SW and (d) Ni-containing precipitate produced by A. aquatilis.

To ensure that the crystalline deposits by A. aquatilis were indeed $\mathrm{CaCO}_{3}$ mineral, $\mathrm{XRD}$ was used to identify the main composition of the precipitation. The main composition identified for normal seawater was $\left(\mathrm{Mg} \cdot{ }_{064} \mathrm{Ca} .936\right)\left(\mathrm{CO}_{3}\right)$, which had three major diffraction of peaks $\left(29.5,48.6\right.$, and $\left.47.5^{\circ}\right)$. For the Ni-contaminated seawater group, $\mathrm{NiCO}_{3}$ was observed on the spectra, as shown in Figure 3, which was consistent with the results of EDS [21,22]. These results indicated that $\mathrm{Ca}^{2+}$ and $\mathrm{Mg}^{2+}$ were removed via biomineralization, and the co-precipitation of $\mathrm{Ni}^{2+}$ was also achieved by A. aquatilis at the same time. 


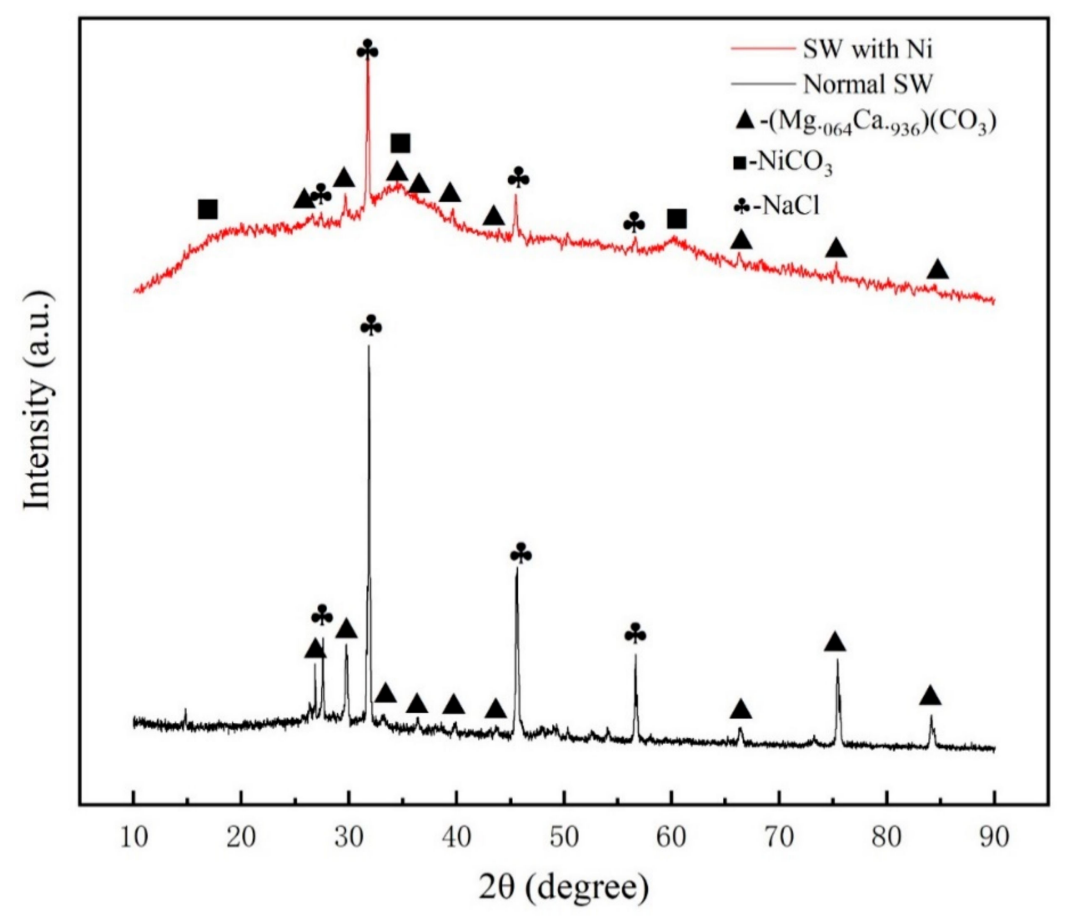

Figure 3. X-ray diffraction of bioprecipitation formed in normal or Ni-containing seawater (SW). Typical data are shown from one of several determinations.

To elucidate the morphologies and structures of the biomineralized precipitates by the A. aquatilis strain, TEM and high-resolution transmission electron microscopy (HRTEM) were performed on day 5 . The TEM images show that the sizes of $\left(\mathrm{Mg} \cdot 064 \mathrm{Ca} .{ }_{936}\right)\left(\mathrm{CO}_{3}\right)$ crystals were approximately $10-150 \mathrm{~nm}$ in diameter, and they nucleated on the surface of the cell (Figure 4a,b). These nanometer-sized precipitates were identified as a mixture of polycrystalline and amorphous structures according to the SAED pattern, exhibiting clear diffraction spots and fuzzy diffuse rings (Figure 4c). HRTEM analyses show that the precipitates were polycrystalline with at least three planes. The lattice spacing of the precipitates is $0.38 \mathrm{~nm}, 0.30 \mathrm{~nm}$, and $0.25 \mathrm{~nm}$, for the (012), (104), and (110) planes, respectively (Figure 4d). Moreover, the lattice spacing of the $\mathrm{NiCO}_{3}$ is $0.27 \mathrm{~nm}, 0.21 \mathrm{~nm}$, and $0.17 \mathrm{~nm}$, for the (104), (113), and (116) planes, respectively (Figure 4f). HRTEM analyses with SAED were consistent with the XRD analysis, and the lattice spacing pattern further confirmed that $\mathrm{NiCO}_{3}$ was present on the bioprecipitates.

The wide scan XPS spectra of a sample collected from the precipitation are shown in Figure 5. Carbon, oxygen, calcium, and nickel were detected as main elements. In Figure $6 \mathrm{a}, \mathrm{b}$, the spectra for $\mathrm{C} 1 \mathrm{~s}$ and $\mathrm{Ni} 2 \mathrm{p} 3$ in the precipitates represent carbonate compounds and $\mathrm{NiCO}_{3}$ formed by the bioremediation [23].

The presence of carbonates was further confirmed via FTIR spectroscopy (Figure 7). A unique spectrum fingerprint can be identified as carbonates, containing a $v 2$ peak at $876 \mathrm{~cm}^{-1}, v 3$ peak at $1426 \mathrm{~cm}^{-1}$, and $v 4$ peak at $712 \mathrm{~cm}^{-1}$. The $1426 \mathrm{~cm}^{-1}$ absorption peak was not as sharp as the other peaks due to the overlap of the vibration of organic matter and inorganic mineral [24]. Furthermore, absorption peaks of organic matter were also observed in the infrared spectra. The peak at $1690 \mathrm{~cm}^{-1}$ represented the $\mathrm{C}=\mathrm{O}$ absorption from carboxylic acid. The $\mathrm{C}-\mathrm{H}$ absorption peak of organic matter was observed between 2800 and $3000 \mathrm{~cm}^{-1}$ [25]. The $3429 \mathrm{~cm}^{-1}$ peak was attributed to the $\mathrm{O}-\mathrm{H}$ bonds. These results suggest that this precipitate was an organic-inorganic material composed of organic matter and carbonates. 


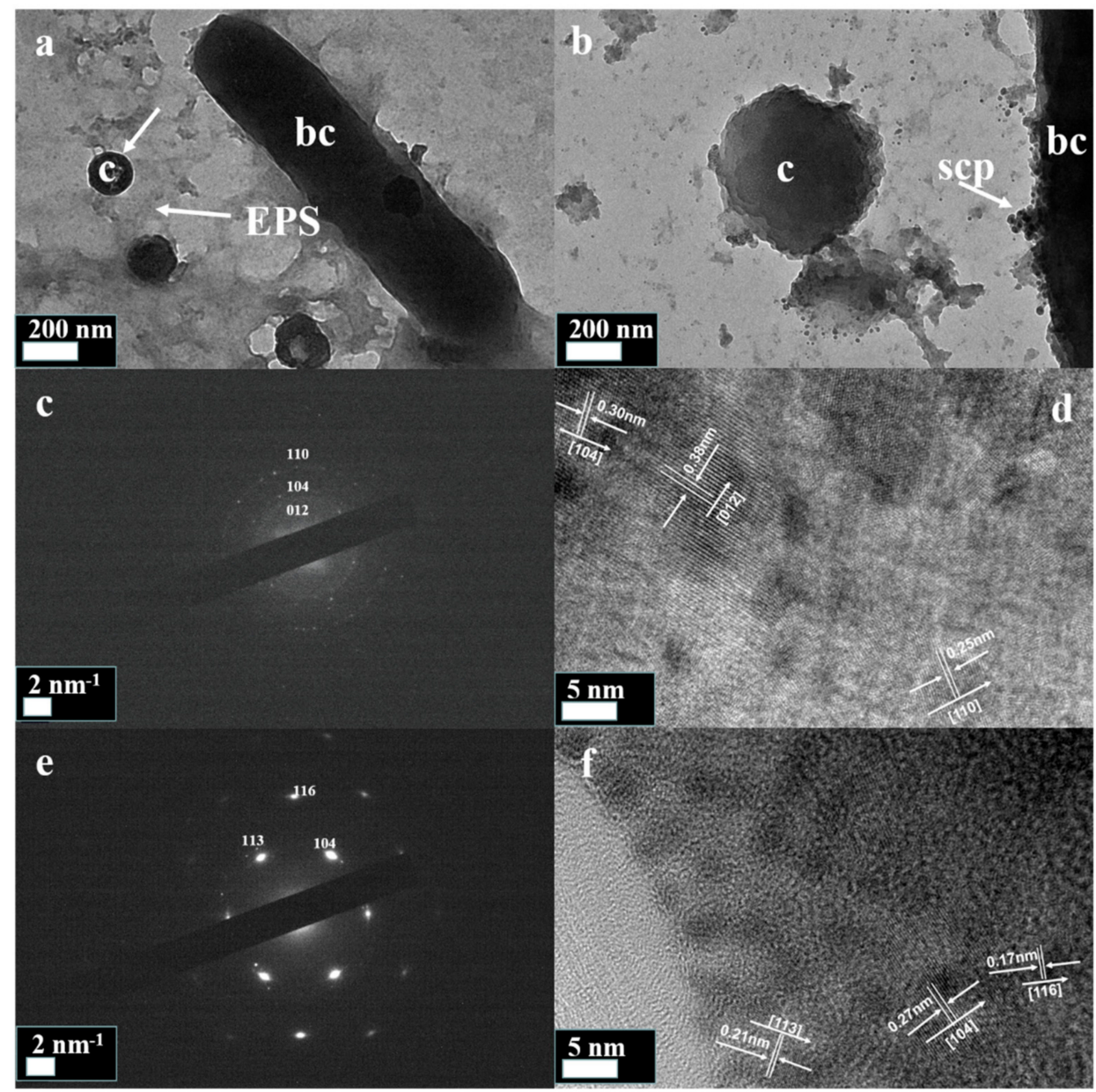

Figure 4. (a) TEM image of the bacterial cell in the marine broth on day 14 during the immersion test. Nanometer-sized precipitates (c) embedded inside energy dispersive spectroscopy (EPS) are attached to the wall of the bacterial cell (BC). (b) Smaller nanometer-sized precipitates (SCP) formed on the cell surface. (c,e) Selected area electron diffraction (SAED) pattern showed that the nanometer-sized precipitates embedded in EPS were a mixture of polycrystalline for $\left(\mathrm{Mg} \cdot{ }_{064} \mathrm{Ca} .{ }_{936}\right)\left(\mathrm{CO}_{3}\right)$ and $\mathrm{NiCO}_{3}$. (d,f) High-resolution transmission electron microscopy (HRTEM) analyses showed that the nanometer-sized precipitates were polycrystalline for $\left(\mathrm{Mg} \cdot 064 \mathrm{Ca} \cdot{ }_{936}\right)\left(\mathrm{CO}_{3}\right)$ and $\mathrm{NiCO}_{3}$.

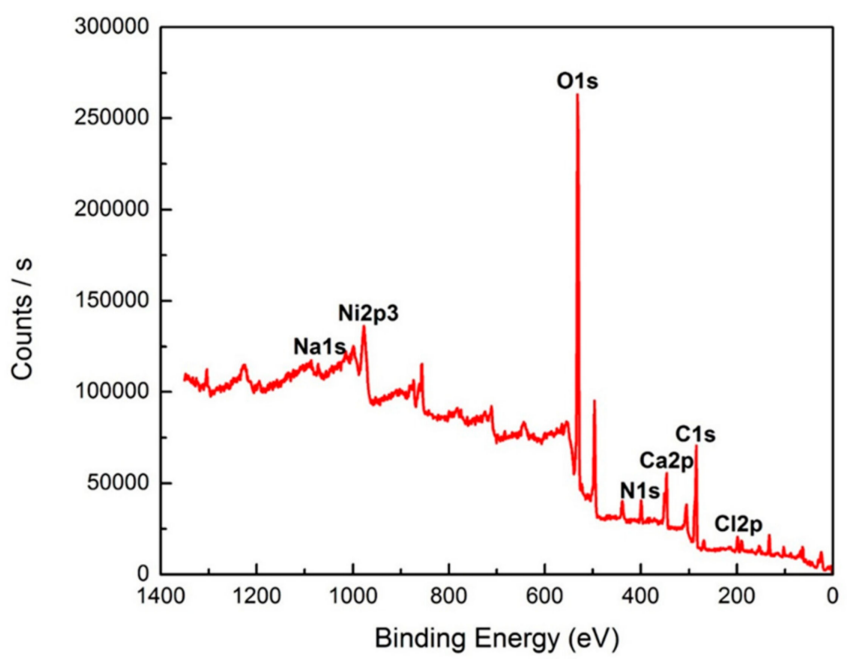

Figure 5. X-ray photoelectron spectroscopy (XPS) spectra of Ni-containing bioprecipitation after microbial-induced carbonate precipitation (MICP). Typical data are shown from one of several determinations. 
a

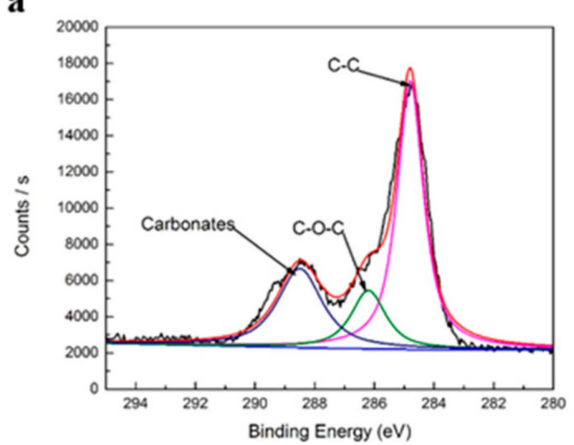

b

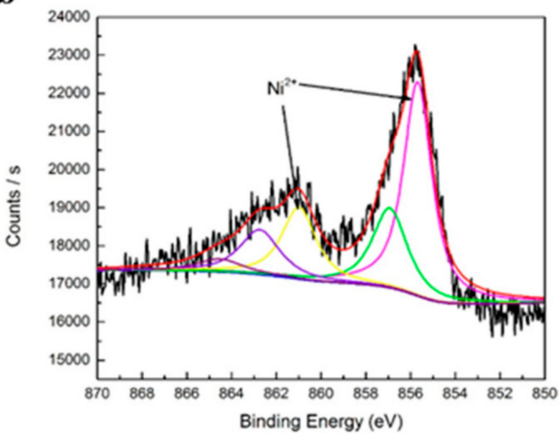

Figure 6. The XPS spectra for (a) C 1s and (b) Ni 2p3 of Ni-containing bioprecipitation after MICP. Typical data are shown from one of several determinations.

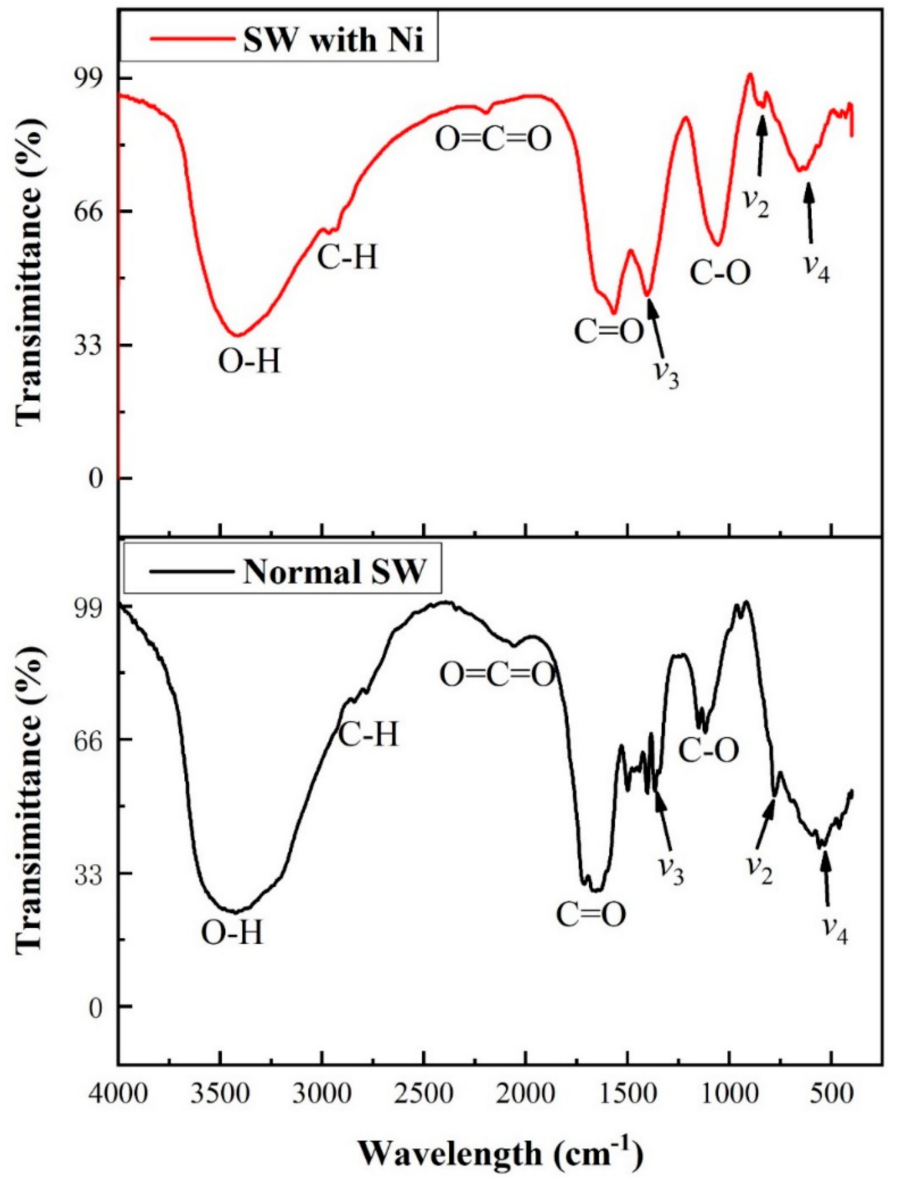

Figure 7. FTIR spectroscopy of bioprecipitation for normal and Ni-containing seawater after bioremediation. Typical data are shown from one of several determinations.

In application of MICP to remove $\mathrm{Ca}, \mathrm{Mg}$, and heavy metal from seawater, ammonia is an unwanted byproduct, which is toxic and harmful to organisms. However, removing ammonia from seawater after MICP has remained an unsolved issue [26]. Interestingly, the Alcaligenes genus has the ability to change ammonia to nitrogen $\left(\mathrm{N}_{2}\right)$ gas in a single aerobic process [27-29]. Compared with traditional methods, this single aerobic process $\left(2 \mathrm{NH}_{4}{ }^{+} \rightarrow 2 \mathrm{NH}_{2} \mathrm{OH} \rightarrow \mathrm{N}_{2}\right)$ is an attractive approach to remove ammonia from wastewater. Herein, the Alcaligenes genus could convert ammonia to $\mathrm{N}_{2}$ in wastewater under an oxygen-rich environment. This could eliminate the toxicity of ammonia [20]. As a result, $A$. aquatilis was applied to convert ammonia to $\mathrm{N}_{2}$ in desalination. In Figure 8 and Table 1 , the 
$66.8 \%$ removal rate indicates that the toxicity of ammonia can be eliminated, and secondary pollution was avoided.

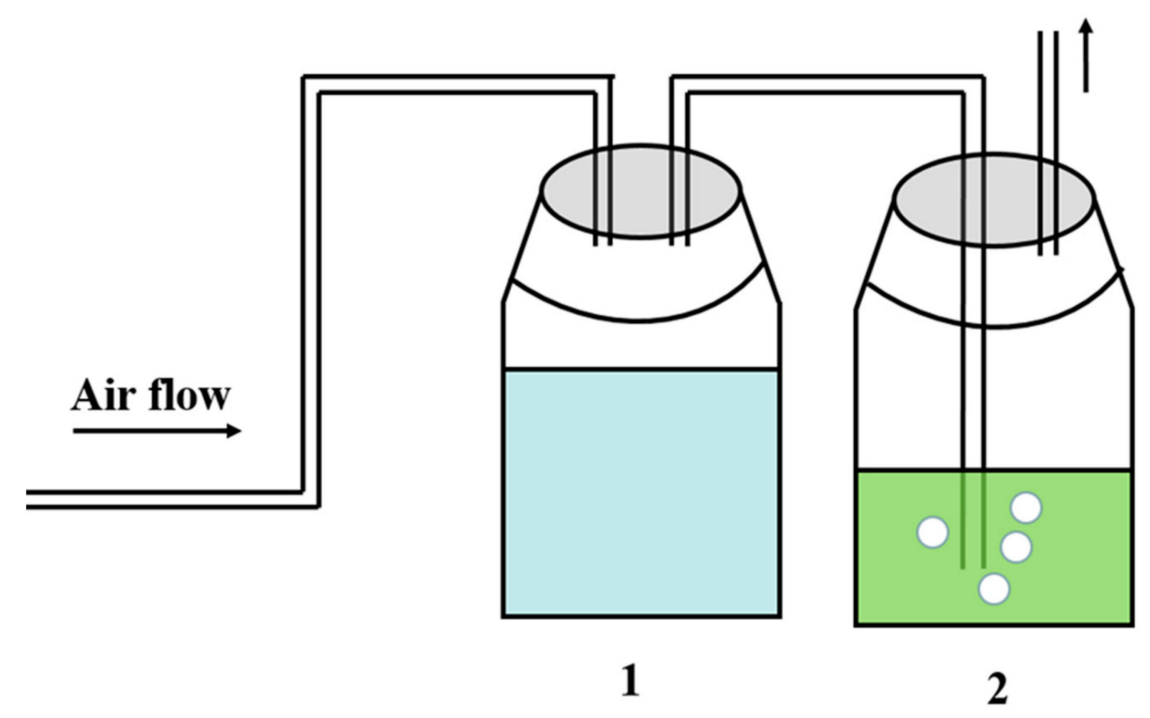

Figure 8. The bioreactor system used to conduct batch experiments: (1) reactor with a magnetic stirrer for aerated experiments and (2) acid trap. The arrows indicate the flow direction of either air or oxygen.

Table 1. Removal rate of ammonia after the MICP process.

\begin{tabular}{cccc}
\hline $\begin{array}{c}\text { Initial Ammonia } \\
(\mathbf{m m o 1} / \mathrm{L})\end{array}$ & $\begin{array}{c}\text { Final Ammonia } \\
(\mathbf{m m o l} / \mathrm{L})\end{array}$ & $\begin{array}{c}\text { Escaped Ammonia } \\
(\mathbf{m m o l} / \mathrm{L})\end{array}$ & Removal Rate (\%) \\
\hline 43.4 & 8.3 & 6.1 & 66.8 \\
\hline
\end{tabular}

\section{Discussion}

In desalination, $\mathrm{Ca}$ and $\mathrm{Mg}$ ions in seawater can cause scale deposition on the reverse osmosis membranes and water treatment systems, and heavy metal ions from wastewater can cause harm to people's health. How to remove $\mathrm{Ca}, \mathrm{Mg}$, and heavy metal ions continues to be a significant question. Numerous approaches, such as chemical precipitation, flotation, ion exchange, adsorption, electrochemical deposition, coagulation, and membrane filtration, are applied in the treatment of metal-containing water [30-32]. Although some of these methods are effective [30], their shortcomings are also obvious, such as high-energy consumption, use of chemicals, toxic metal sludge production, and huge overall costs [33]. Based on these restraints, as eco-friendly alternatives, biological methods, such as bioaccumulation, bio-sorption, bio-coagulation, phytoremediation and bioleaching, have been applied for metal removal from water [34,35]. Moreover, the addition of precipitants has a limited effective period. The approach of biomineralization has a long lasting effect due to the self-culture of bacteria in the medium. Biomineralization is a process that precipitates calcium and magnesium ions in seawater via microbial metabolism. Furthermore, the organic carbon and nitrogen sources in seawater provide nutrients for the growth and reproduction of bacteria. Therefore, the desalination can be continuously performed by the durable process of biomineralization in seawater. Herein, a novel biological method was performed to reduce the dissolved $\mathrm{Ca}, \mathrm{Mg}$, and $\mathrm{Ni}$ in seawater without the addition of urea. MICP by A. aquatilis removed $93.6 \%, 72.4 \%$, and $92.2 \%$ of the initial soluble Ca, $\mathrm{Mg}$, and $\mathrm{Ni}$, respectively. High-efficiency removal of $\mathrm{Ni}$ by A. aquatilis indicates that this process has broad application potential for desalination of seawater containing heavy metals, such as chromium, cadmium, and cobalt.

The EPS surrounding bacteria cells contains a series of functional groups that can adsorb metal ions in the solution [36]. According to our earlier work, abundant polysaccharides in EPS enhance carbonate precipitates [21]. Nickel carbonate nucleated in the EPS surrounding cells via the reaction 
of $\mathrm{Ni}^{2+}$ with $\mathrm{HCO}_{3}{ }^{-}$. The nickel carbonate then grew and broke away from the cells. These results suggest that abundant EPS and $\mathrm{HCO}_{3}{ }^{-}$generation from the decomposition of protein or amino acids contributes to the precipitation of nickel carbonate. A. aquatilis strains with abundant EPS could decompose protein or amino acids, and this process has great potential for Ni removal. The process of reaction might take the following form:

$$
\begin{gathered}
\text { A. aquatilis + protein or amino acid } \rightarrow \mathrm{NH}_{4}{ }^{+}+\mathrm{CO}_{3}{ }^{2-} \\
\mathrm{EPS}+\mathrm{Ca}^{2+}+\mathrm{Ni}^{2+} \rightarrow \mathrm{Ni}^{2+} \text {-EPS-Ca }{ }^{2+} \\
\mathrm{Ni}^{2+} \text {-EPS-Ca }{ }^{2+}+2 \mathrm{CO}_{3}{ }^{2-} \rightarrow \mathrm{NiCO}_{3}+\mathrm{CaCO}_{3} .
\end{gathered}
$$

Another factor affecting carbonate precipitates was alkalinity. Higher $\mathrm{pH}$ values helped the solution reach the saturation index of carbonate in the solution $[12,13]$. The bacterium A. aquatilis could decompose protein or amino acids to generate the $\mathrm{NH}_{4}{ }^{+}$and $\mathrm{HCO}_{3}{ }^{-}$in the solution, increasing the $\mathrm{pH}$ value of the solution.

Therefore, bacteria that can be used in desalination possess have three characteristics: 1) The bacterial strain can produce abundant EPS, which could provide nucleation sites. 2) The bacteria can decompose protein or amino acids to carbonate and ammonium. 3) The bacteria have the unique ability to change ammonia to the nitrogen $\left(\mathrm{N}_{2}\right)$ gas in a single aerobic process. Despite such advances, some key gaps remain in the application. In our future work, it is necessary to optimize biomineralization conditions for potential use in the various complex environments.

\section{Conclusions}

Marine bacterium A. aquatilis removes $\mathrm{Ca}, \mathrm{Mg}$, and $\mathrm{Ni}$ in seawater via a MICP process. Compared with the traditional methods, $A$. aquatilis can utilize organic matter via an amination reaction, which produces carbonate to precipitate the $\mathrm{Ca}, \mathrm{Mg}$, and $\mathrm{Ni}$ ions, avoiding the use of urea. After the MICP treatment, $A$. aquatilis can further remove harmful ammonium under oxygen-rich conditions. Therefore, the application of bacterium A. aquatilis for improving seawater quality is of great importance for desalination.

Author Contributions: Conceptualization, Z.G.; methodology, Y.D.; software, Y.D.; validation, N.G.; formal analysis, T.L.; investigation, Y.D.; supervision, Z.G.

Funding: This research was funded by National Natural Science Foundation of China (51901127 and 41976039), China Postdoctoral Science Foundation (2018M641980) and Shanghai Natural Science Fund (19ZR1422100).

Acknowledgments: We thank LetPub (www.letpub.com) for its linguistic assistance during the preparation of this manuscript.

Conflicts of Interest: The authors declare no conflicts of interest.

\section{References}

1. Lattemann, S.; Höpner, T. Environmental impact and impact assessment of seawater desalination. Desalination 2008, 220, 1-15. [CrossRef]

2. Mohamed, K.; Talamali, A.; Smaili, Y.; Saadoun, I. Environmental impact of seawater desalination plants: Case study in Algeria. Am. J. Environ. Sustain. 2013, 2, 141-148. [CrossRef]

3. Arias, D.; Cisternas, L.; Rivas, M. Biomineralization mediated by ureolytic bacteria applied to water treatment: A review. Crystals 2017, 7, 345. [CrossRef]

4. Arias, D.; Cisternas, L.; Rivas, M. Biomineralization of calcium and magnesium crystals from seawater by halotolerant bacteria isolated from Atacama Salar (Chile). Desalination 2017, 405, 1-9. [CrossRef]

5. Miller, S.; Shemer, H.; Semiat, R. Energy and environmental issues in desalination. Desalination 2015, 366, 2-8. [CrossRef] 
6. Mitchell, A.C.; Ferris, F.G. The coprecipitation of Sr into calcite precipitates induced by bacterial ureolysis in artificial groundwater: Temperature and kinetic dependence. Geochim. Cosmochim. Acta 2005, 69, 4199-4210. [CrossRef]

7. Mwandira, N.K.; Kawasaki, W.S. Bioremediation of lead-contaminated mine waste by Pararhodobacter sp. based on the microbially induced calcium carbonate precipitation technique and its effects on strength of coarse and fine grained sand. Ecol. Eng. 2017, 109, 57-64. [CrossRef]

8. Takumi Horiike, Y.D.; Nakano, Y.; Ochiai, A.; Utsunomiya, S.; Ohnuki, T.; Yamashita, M. Removal of soluble strontium via incorporation into biogenic carbonate minerals by halophilic bacterium Bacillus sp. strain TK2d in a highly saline solution. Appl. Environ. Microb. 2017, 83, e00855-17.

9. Bai, Y.; Guo, X.J.; Li, Y.Z.; Huang, T. Experimental and visual research on the microbial induced carbonate precipitation by Pseudomonas aeruginosa. AMB Express 2017, 7, 1-9. [CrossRef]

10. Govarthanan, M.; Lee, K.-J.; Cho, M.; Kim, J.S.; Kamala-Kannan, S.; Oh, B.T. Significance of autochthonous Bacillus sp. KK1 on biomineralization of lead in mine tailings. Chemosphere 2013, 90, 2267-2272. [CrossRef]

11. Kumeta, Y.; Inami, K.; Ishimaru, K.; Yamazaki, Y.; Sameshima-Saito, R.; Saito, A. Thermogravimetric evaluation of chitin degradation in soil: Implication for the enhancement of ammonification of native organic nitrogen by chitin addition. Soil Sci. Plant Nutr. 2018, 64, 512-519. [CrossRef]

12. Zhu, Y.; Ma, N.; Jin, W.; Wu, S.; Sun, C. Genomic and transcriptomic insights into calcium carbonate biomineralization by marine Actinobacterium brevibacterium linens BS258. Front. Microbiol. 2017, 8, 602. [CrossRef] [PubMed]

13. Achal, V.; Pan, X.; Zhang, D. Remediation of copper-contaminated soil by Kocuria flava CR1, based on microbially induced calcite precipitation. Ecol. Eng. 2011, 37, 1601-1605. [CrossRef]

14. Anbu, P.; Kang, C.H.; Shin, Y.J.; So, J.S. Formations of calcium carbonate minerals by bacteria and its multiple applications. SpringerPlus 2016, 5, 250. [CrossRef]

15. Van Paassen, L.A.; Daza, C.M.; Staal, M.; Sorokin, D.Y.; Van der Zon, W.; Van Loosdrecht, M.C.M. Potential soil reinforcement by biological denitrification. Ecol. Eng. 2010, 36, 168-175. [CrossRef]

16. Van Trappen, S.; Tan, T.L.; Samyn, E.; Vandamme, P. Alcaligenes aquatilis sp. nov., a novel bacterium from sediments of the Weser Estuary, Germany, and a salt marsh on Shem Creek in Charleston Harbor, USA. Int. J. Syst. Evol. Microbiol. 2005, 55, 2571-2575. [CrossRef]

17. Zhang, Y.; Chen, Q.; Ji, J.; Zhao, L.; Zhang, L.; Qiu, J.; He, J. Complete genome sequence of Alcaligenes faecalis strain JQ135, a bacterium capable of efficiently degrading nicotinic acid. Curr. Microbiol. 2018, 75, 1551-1554. [CrossRef]

18. Cheng, H.; Zhang, X.; Song, H. Morphological investigation of calcium carbonate during ammonificationcarbonization process of low concentration calcium solution. J. Nanomater. 2014, 2014, 503696. [CrossRef]

19. Krause, S.; Liebetrau, V.; Löscher, C.R.; Böhm, F.; Gorb, S.; Eisenhauer, A.; Treude, T. Marine ammonification and carbonic anhydrase activity induce rapid calcium carbonate precipitation. Geochim. Cosmochim. Acta 2018, 243, 116-132. [CrossRef]

20. Neerackal, G.M.; Ndegwa, P.M.; Joo, H.S.; Wang, X.; Frear, C.S.; Harrison, J.H.; Beutel, M.W. Potential application of Alcaligenes faecalis strain No. 4 in mitigating ammonia emissions from dairy wastewater. Bioresour. Technol. 2016, 206, 36-42. [CrossRef]

21. Liu, T.; Guo, Z.; Zeng, Z.; Guo, N.; Lei, Y.; Liu, T.; Sun, S.; Chang, X.; Yin, Y.; Wang, X. Marine bacteria provide lasting anticorrosion activity for steel via biofilm-induced mineralization. ACS Appl. Mater. Interfaces 2018, 10, 40317-40327. [CrossRef] [PubMed]

22. Ando, H.; Kawamoto, D.; Ohashi, H.; Honma, T.; Ishida, T.; Okaue, Y.; Tokunaga, M.; Yokoyama, T. Adsorption behavior of $\mathrm{Au}(\mathrm{III})$ complex ion on nickel carbonate and nickel hydroxide. Colloid Surf. A 2018, 537, 383-389. [CrossRef]

23. Ko, J.W.; Son, E.J.; Park, C.B. Nature-inspired synthesis of nanostructured electrocatalysts through mineralization of calcium carbonate. ChemSusChem 2017, 10, 2585-2591. [CrossRef] [PubMed]

24. Oppenheimer-Shaanan, Y.; Sibony-Nevo, O.; Bloom-Ackermann, Z.; Suissa, R.; Steinberg, N.; Kartvelishvily, E.; Brumfeld, V.; Kolodkin-Gal, I. Spatio-temporal assembly of functional mineral scaffolds within microbial biofilms. NPJ Biofilms Microbiomes 2016, 2, 15031. [CrossRef]

25. Pokroy, B.; Quintana, J.P.; Caspi, E.N.; Berner, A.; Zolotoyabko, E. Anisotropic lattice distortions in biogenic aragonite. Nat. Mater. 2004, 3, 900-902. [CrossRef] 
26. Torres-Aravena, Á.; Duarte-Nass, C.; Azócar, L.; Mella-Herrera, R.; Rivas, M.; Jeison, D. Can microbially induced calcite precipitation (micp) through a ureolytic pathway be successfully applied for removing heavy metals from wastewaters? Crystals 2018, 8, 438. [CrossRef]

27. Joo, H.S.; Hirai, M.; Shoda, M. Characteristics of ammonium removal by heterotrophic nitrification-aerobic denitrification by Alcaligenes faecalis No. 4. J. Biosci. Bioeng. 2005, 100, 184-191. [CrossRef]

28. Joo, H.S.; Hirai, M.; Shoda, M. Piggery wastewater treatment using Alcaligenes faecalis strain No. 4 with heterotrophic nitrification and aerobic denitrification. Water Res. 2006, 40, 3029-3036. [CrossRef]

29. Joo, H.S.; Hirai, M.; Shoda, M. Improvement in ammonium removal efficiency in wastewater treatment by mixed culture of Alcaligenes faecalis No. 4 and L1. J. Biosci. Bioeng. 2007, 103, 66-73. [CrossRef]

30. Fu, F.; Wang, Q. Removal of heavy metal ions from wastewaters: A review. J. Environ. Manag. 2011, 92, 407-418. [CrossRef]

31. Ilhan, S.; Nourbaksh, M.; Kilicarslan, S.; Ozdag, H. Removal of chromium, lead and copper ions from industrial waste waters by Staphylococcus saprophyticus. Turk. Electron. J. Biotechnol. 2004, 2, 50-57.

32. Barakat, M.A. New trends in removing heavy metals from industrial wastewater. Arab. J. Chem. 2011, 4, 361-377. [CrossRef]

33. Arbabi, M.; Hemati, S.; Amiri, M. Removal of lead ions from industrial wastewater: A review of Removal. Int. J. Epidemiol. Res. 2015, 2, 105-109.

34. Ahluwalia, S.S.; Goyal, D. Microbial and plant derived biomass for removal of heavy metals from wastewater. Bioresour. Technol. 2007, 98, 2243-2257. [CrossRef]

35. Nancharaiah, Y.V.; Mohan, S.V.; Lens, P.N.L. Biological and Bioelectrochemical Recovery of Critical and Scarce Metals. Trends Biotechnol. 2016, 34, 137-155. [CrossRef] [PubMed]

36. Nishimura, T. Macromolecular templates for the development of organic/inorganic hybrid materials. Polym. J. 2014, 47, 235-243. [CrossRef]

(C) 2019 by the authors. Licensee MDPI, Basel, Switzerland. This article is an open access article distributed under the terms and conditions of the Creative Commons Attribution (CC BY) license (http://creativecommons.org/licenses/by/4.0/). 